\title{
Clinical Profile of Renal Cell Carcinoma- A Retrospective Descriptive Study
}

\author{
Gurana Krishna Rao1, Mallireddy Ramachandra², Mutyala Vijay Durga Pradad³, Prem Kamal Patnala4, \\ Dhanya Charitha Dwarapureddy ${ }^{5}$
}

\begin{abstract}
${ }^{1}$ Senior Resident, Department of General Surgery, Rangaraya Medical College, Kakinada, Andhra Pradesh, India. ${ }^{2}$ Associate Professor, Department of General Surgery, Rangaraya Medical College, Kakinada, Andhra Pradesh, India. ${ }^{3}$ Postgraduate Student, Department of General Surgery, Rangaraya Medical College, Kakinada, Andhra Pradesh, India. ${ }^{4}$ Postgraduate Student, Department of General Surgery, Rangaraya Medical College, Kakinada, Andhra Pradesh, India. ${ }^{5}$ Postgraduate Student, Department of General Surgery, Rangaraya Medical College, Kakinada, Andhra Pradesh, India.
\end{abstract}

\section{ABSTRACT}

\section{BACKGROUND}

RCC is the most frequent primary tumour of the kidney. It constitutes about $3 \%$ of adult malignancies. Worldwide incidence is increasing at an annual rate of about $2 \%$. Recent trends show a gradual increase in the incidence of RCC. We wanted to study the clinical profile of renal cell carcinoma and evaluate the post-op period of radical nephrectomy.

\section{METHODS}

A retrospective descriptive study of all patients diagnosed with renal cell carcinoma, from 2013 to 2018, were studied in all clinical aspects and evaluated.

\section{RESULTS}

The study showed male preponderance, most common age group being 60 to 70 years. Most patients were from rural background and presented with flank pain. Triad of mass per abdomen, flank pain and hematuria was present in $8 \%$ cases. $65 \%$ patients were hypertensive, $55 \%$ were smokers, $55 \%$ were alcoholics, $40 \%$ were diabetic. Most tumours are left sided. CECT Abdomen predicted resectability in all cases. Radical nephrectomy is a relatively safe surgery with less morbidity of 10 to 14 days of hospital stay post operatively. Mortality was $10 \%$, common cause of mortality was pulmonary infection. Clear cell type is the most common histological variant

\section{CONCLUSIONS}

Males above 50 years, with flank pain should be evaluated with RCC as a differential diagnosis. Screening for RCC plays an important role in diagnosing early tumours leading to better prognosis. Populations with risk factors like hypertension, smoking and diabetes, in their $5^{\text {th }}$ decade should be screened for RCC. Trans-peritoneal approach for RCC is safe. Radical nephrectomy has relatively low mortality with an average postop stay of 10 to 14 days. Proper pre-operative evaluation and addressing the cardiac, pulmonary issues decreases the post-operative mortality.

\section{KEY WORDS}

Renal Cell Carcinoma, Nephrectomy
Corresponding Author:

Dr. Mallireddy Ramachandra, Associate Professor,

Department of General Surgery, GGH/RMC, Kakinada, East Godavari Dist. Andhra Pradesh, India.

E-mail:drmrchandra@yahoo.com

DOI: $10.14260 /$ jemds/2019/544

Financial or Other Competing Interests: None.

How to Cite This Article:

Rao GK, Ramachandra M, Prasad MVD, et al. Clinical profile of renal cell carcinoma- $a$ retrospective descriptive study. J. Evolution Med. Dent. Sci. 2019;8(31):2500-2503, DOI: 10.14260/jemds/2019/544

Submission 27-03-2019,

Peer Review 20-07-2019,

Acceptance 27-07-2019,

Published 05-08-2019. 


\section{BACKGROUND}

Renal cell carcinoma is found to be responsible for $2.4 \%$ of world's total cancer burden.[1] Contributing to $1.7 \%$ of all deaths in world, RCC stands as one of the deadly urinary tract cancers ${ }^{[1]}$ and one among the ten most common cancers. ${ }^{[2]}$ Temporal trends have shown increase in the incidence of RCC over past 3 decades.[3] This increase in incidence can be attributed to the recent development and utility of imaging modalities.[2,4] Heidelberg classified the histological types of RCC into clear cell type, papillary type, chromophobe type, collecting duct type and unclassified type of which clear cell type is the most common(80\%).[5,6] Lack of early warning signs and vague clinical features make management of these cancers challenging. ${ }^{[7]}$ Surgery is the best treatment of choice, radical nephrectomy being the most commonly performed surgery. Small and localized RCC can be effectively managed with surgery with much decreased disease specific mortality and morbidity ${ }^{[8]}$ and likelihood of metastasis increases with increased stage of RCC.[9] Conventional chemotherapy is responsive in only 15 to $25 \%$ of metastatic RCC with associated serious adverse effects ${ }^{[10]}$ with 5 year survival rate of $<10 \%$.[11] Novel therapy with sunitinib, sorafenib, temsirolimus, bevacizumab showed promising results recently. ${ }^{[12]}$ In this contest, studying the clinical profile of RCC helps in better management of cases, in the light of recent increase in the incidence of RCC. $[3,4,8]$

We wanted to study the clinical profile of renal cell carcinoma and evaluate the post-op period of radical nephrectomy.

\section{METHODS}

\section{Study Type}

A retrospective descriptive study.

\section{Sample}

All patients who underwent radical nephrectomy with diagnosis of renal cell cancer, from 2013 to 2018, were studied retrospectively. Patients whose post op biopsy showed renal cell carcinoma were studied clinically and analysed.

\section{Sample Size}

37.

\section{Statistical Analysis}

Patients were studied and followed with respect to-

- Incidence in view of age, sex, locality and chief complaint.

- Relevant medical and personal history.

- Laterality.

- Radiological aspects.

- Post op aspects of nephrectomy.

- Pathological variety.

Data was collected from

- MRD section: case sheets.

- Radiology Dept.: USG, CECT Abdomen reports.

- Pathology Dept.: HPE reports.

\section{RESULTS}

Out of the 37 patients, all the patients were above the age of 30 years. $30 \%$ of patients were of age group 60 to 70 years while $25 \%$ were of 50 to 60 years age group, another $25 \%$ were of 40 to 50 years age group. But only $15 \%$ of these patients were of age less than 40 years.

\begin{tabular}{|c|c|c|}
\hline Age Groups & & $5 \%$ \\
\hline$>70$ & 2 & $30 \%$ \\
\hline 60 to 70 & 12 & $25 \%$ \\
\hline 50 to 60 & 9 & $25 \%$ \\
\hline 40 to 50 & 5 & $15 \%$ \\
\hline 30 to 40 & 5 & \\
\hline \multicolumn{3}{|c|}{ Table 1. Incidence Among Age Groups } \\
\hline
\end{tabular}

\begin{tabular}{|c|c|c|}
\hline Sex & Incidence & Percentage \\
\hline males & 20 & 55 \\
\hline females & 17 & 45 \\
\hline \multicolumn{3}{|c|}{ Table 2. Gender Wise Incidence } \\
\hline Males were of 55\% and females were of 45\%.
\end{tabular}

\begin{tabular}{|c|c|c|}
\hline Locality & Incidence & Percentage \\
\hline Urban & 2 & $5 \%$ \\
\hline Rural & 33 & $90 \%$ \\
\hline tribal & 2 & $5 \%$ \\
\hline \multicolumn{3}{|c|}{ Table 3. Locality Wise Distribution } \\
\hline Most of the patients were from rural background who amount up to $90 \% .5 \%$ of
\end{tabular}
patient were from urban population and $5 \%$ were from tribal population.

\begin{tabular}{|c|c|c|}
\hline Complaint & 11 & $30 \%$ \\
\hline Mass Per abdomen & 7 & $20 \%$ \\
\hline Haematuria & 19 & $50 \%$ \\
\hline Flank Pain & Table 4. Symptomatology \\
\hline \multicolumn{3}{|c|}{} \\
\hline $\begin{array}{l}\text { Most of the patients (50\%) presented with flank pain as their chief complaint. 30\% of } \\
\text { patients presented with mass per abdomen. Hematuria, a specific symptom of } \\
\text { urological pathology, was the chief complaint in only 20\% cases. Triad of mass per } \\
\text { abdomen, hematuria and flank pain found in 3 out of 37(8\%) of patients. }\end{array}$ \\
\hline \multicolumn{3}{|l|}{} \\
\hline
\end{tabular}

\begin{tabular}{|c|c|c|}
\hline & Incidence & Percentage \\
\hline Alcoholic & 21 & $55 \%$ \\
\hline Smoking & 21 & $55 \%$ \\
\hline Hypertension & 24 & $65 \%$ \\
\hline Diabetics & 15 & $40 \%$ \\
\hline \multicolumn{3}{|c|}{ Table 5. Risk Factors } \\
\hline 65\% of the patients were associated with hypertension. Smoking was associated
\end{tabular}

with $55 \%$ of patients and $55 \%$ were alcoholics. $40 \%$ were Diabetics.

\begin{tabular}{|c|c|c|}
\hline Side & Incidence & Percentage \\
\hline Left & 28 & $75 \%$ \\
\hline Right & 9 & $25 \%$ \\
\hline \multicolumn{3}{|c|}{ Table 6. Laterality } \\
\hline $\begin{array}{l}\text { 75\% of patients had renal cell carcinoma arising from left kidney only and 25\% of } \\
\text { patients had renal cell carcinoma arising from right kidney only. Bilateral renal cell } \\
\text { carcinoma was not encountered. }\end{array}$ \\
\hline
\end{tabular}

\section{CECT Abdomen}

- All patients were diagnosed to have a renal mass in ultrasound.

- All patients had radiological findings consistent with renal cell carcinoma on CECT abdomen.

- CECT abdomen findings correlated well with intra operative findings regarding staging, tumour extent and vascular involvement.

- Renal vein thrombosis was not been encountered in any of the 37 patients radiologically.

\section{Blood Investigations}

$40 \%$ of patients had haemoglobin level less than $8 \mathrm{gm} / \mathrm{dl}$. All the patient had total leucocyte count within the range of 4000 to 11000 . All the patients had ESR with in the range of 6 to $21 \mathrm{~mm}$ in one hour. 


\section{Complications following Nephrectomy}

- All patients were approached through trans peritoneal route.

- $49 \%$ of patients had not developed any complication in the post-operative period.

- $\quad 41 \%$ of patients developed wound infection.

- $10 \%$ of patients developed retroperitoneal collection.

Most of the patients needed at least one packet of RBC for transfusion, $25 \%$ of the patients required 2 packets of $\mathrm{RBC}$.

\section{Post-Operative Hospital Stay}

- $55 \%$ of patients stayed for a period of 10 to 14 days post operatively.

- $20 \%$ of patients stayed for a period of 7 to 10 days.

- Another $20 \%$ of patients stayed for a period of more than 14 days.

- $\quad 5 \%$ of patient were discharged in less than 7 days.

\section{Mortality}

- $\quad$ Out of 37 patients who underwent surgery, 4 suffered death in post op stay.

- Out of which.

- 1 suffered death due to post-operative myocardial infarction.

- 2 suffered death due to pulmonary infection.

- 1 suffered death due to stroke.

\section{Histopathological Type}

30 out of 37 (81\%) of post nephrectomy specimens showed clear cell type. 7 (19\%) specimens showed papillary type of renal cell carcinoma.

\section{Summary}

- $\quad$ RCC is more common in men.

- Commonly affecting people of age group > 50 years age.

- More common in rural areas.

- Most Common presentation is flank pain.

- Hematuria is only present in $30 \%$ cases.

- $65 \%$ were found to be hypertensive.

- $55 \%$ were found to be diabetic.

- $55 \%$ patients had history of alcoholism.

- $55 \%$ patients had history of smoking.

- In this sample, RCC was more common on left side.

- Wound infection was the common post op complication.

- Pulmonary infection was found to be the common cause for post op mortality.

- Clear cell type is the common histological type.

- $\quad$ Minimum 2 packets of blood needed on an average for radical nephrectomy.

Post-operative stay is 10 to 14 days.

\section{DISCUSSION}

Most of the patients in our study were of age 60 to 70 years (30\%) and $55 \%$ of our patients were above 50 years, indicating that RCC, a disease of older population. These results were consistent with studies of $\mathrm{Ng}$ Cs et al. with average of diagnosis is 66 years, ${ }^{[4]}$ Uchida $\mathrm{T}$ et al. with average of presentation is $\mathbf{5 8 . 3}$ years,[13] Veronica Wendy et al. with average age of 65 years.[14] Male to female sex ratio in this study was 1. 17: 1 , showing RCC predominance in males. Ng Cs et al. showed RCC, 2 to 3 times more common in males.[4] Motzer RJ et al. showed that RCC, 2 to 3 times common in male population. [7] Uchinda $\mathrm{T}$ et al. showed a sex ratio of 1.6:1.[13] These showed an increased prevalence of RCC in men aged more than 50 years, screening programs for RCC should include males above 50 years. Hypertension was associated with $65 \%$ of the patients in our study. Prevalence of hypertension was $40 \%$ in a study by Veronica Wendy et al.[14] Chow WH et al. pointed out that increased hypertension, mainly increased systolic blood pressure, increased the risk of RCC.[15] Chow WH, Dong LM et al. showed hypertension is associated with RCC.[3] $55 \%$ of patients in our study were smokers. Chow WH, Dong LM et al.[3] Cho E et al.[16] Veronica Wendy et al.[14] identified the association of smoking with RCC. DeCastro GJ et al., in their study showed that effective treatment of HTN, smoking and obesity decreases the incidence of RCC in future.[8] $40 \%$ of patients were associated with diabetes in our study. Chow WH, Dong LM et al.[3] and Veronica Wendy et al. [14] pointed the association of diabetes with RCC.[3,14] $55 \%$ of patients in our study were known alcoholics. The association of RCC with alcoholism was controversial. Chow WH, Dong LM et al. showed that alcohol is not associated with RCC.[3] Veronica Wendy et al. pointed that alcoholism is inversely associated with risk of RCC in females.[14] In their study, 31\% lower risk was found in men who drank $>1$ drink per day, when compared with nondrinkers. ${ }^{[14]}$ Mc Laughlin et al. observed that alcoholism is not a demonstrable risk for RCC.[17]

Most patients were found to be of rural background. Most of our patients had flank pain as their chief complaint (50\%) followed by mass per abdomen (30\%) and hematuria (20\%). But only 3 out of 37 patients (8\%) had all the three symptoms (Triad of RCC - hematuria, flank pain, mass per abdomen). Uchida $\mathrm{T}$ et al. pointed the most common clinical feature as macroscopic hematuria, followed by asymptomatic, followed by lumbar pain and mass per abdomen.[13] Cairns $\mathrm{P}$ et al documented the triad in $10 \%$ cases, identified that more than $40 \%$ had none of these features and more than $60 \%$ are asymptomatic.[11] RCC is well known for its protean clinical manifestations. ${ }^{[7]}$ Gibbons RP et al. found more than $50 \%$ had vague GI symptoms.[18] Screening plays an important role in identifying early RCC. Patients with one of the symptoms of RCC triad should be thoroughly investigated for RCC. Patients with vague GI symptoms should be evaluated for RCC, as there is an high chance of missing RCC, if their GI evaluation remain normal.[18]

All patients (100\%) were diagnosed with RCC on radiological basis (Solid tumour arising from kidney with arterial enhancement on intravenous contrast) on CECT abdomen preoperatively. CECT abdomen in all patients $(100 \%)$ demonstrated findings consistent with intra operative findings about tumour extent and renal vein involvement. Kovacs et al. identified CECT abdomen as the main modality of imaging.[5] MRI is useful if CT cannot be performed (In pregnant and in patients with iodinated contrast allergy). ${ }^{[5]}$ In our study, $75 \%$ of patients had RCC on left side.

Radical nephrectomy was a relatively well tolerated surgery with less complications. All patients were approached through trans peritoneal approach. None of the patients sustained major intra operative complications. Trans 
peritoneal approach was a convenient approach for nephrectomy with good control of renal pedicles. $49 \%$ patients had no post op complications and most common complication is wound infection (41\%) followed by retroperitoneal collection (10\%).

Most of the patients in our study were discharged within 10 to14 postoperative day (55\%). These were consistent with results of Jones J et al, with mean discharge after 11 days. Postoperative mortality was mainly related to the general condition of the patient. Four patients sustained death in their post-operative period, out of the four deaths, 2 patients died of pulmonary infection, one with post op MI and other with post op stroke. Hutson et al. identified bleeding as most common complication of death, followed by sepsis, arrhythmias, renal failure and pulmonary embolism. Proper pre-operative evaluation of patients and management of risk factors decreases the post-operative mortality. Identified to have more than 10 histological varieties of RCC, clear cell type is the most common variety followed by papillary type, as identified by many studies.[5,6]

\section{CONCLUSIONS}

Males above 50 years, with flank pain should be evaluated for renal cell carcinoma as a differential diagnosis. Clinical manifestations of renal cell carcinoma are vague, screening for renal cell carcinoma plays an important role in diagnosing early tumours leading to better prognosis. Populations with risk factors like hypertension, smoking and diabetes, in their $5^{\text {th }}$ decade should be screened for renal cell carcinoma. Ultrasonography has high sensitivity in evaluating renal cell carcinoma and can be used for screening. Effective management of hypertension, smoking and diabetes can lower the risk of renal cell carcinoma. CECT abdomen is the investigation of choice for renal cell carcinoma both for screening and operative evaluation. Trans-peritoneal approach for renal cell carcinoma is safe, as this approach helps in better intra operative staging and gives good pedicle control. Radical nephrectomy has relatively low mortality with an average postop stay of 10 to 14 days. Proper pre-operative evaluation and addressing the cardiac, pulmonary issues decreases the post-operative mortality.

\section{REFERENCES}

[1] Mohammadian M, Pakzad R, Towhidi F, et al. Incidence and mortality of kidney cancer and its relationship with HDI (Human Development Index) in the world in 2012. Clujul Medical 2017;90(3):286-93.
[2] The American Cancer Society medical and editorial content team. Key statistics about kidney cancer. Last Revised on January 4, 2018. https://www.cancer.org/cancer/kidneycancer/about/key-statistics.html

[3] Chow WH, Dong LM, Devesa SS. Epidemiology and risk factors for kidney cancer. Nature Reviews Urology 2010;7(5):245-57.

[4] Ng CS, Wood CG, Silverman PM, et al. Renal cell carcinoma: diagnosis, staging, and surveillance. American Journal of Roentgenology 2008;191(4):1220-32.

[5] Kovacs G, Akhtar M, Beckwith BJ, et al. The Heidelberg classification of renal cell tumours. The Journal of Pathology: A Journal of the Pathological Society of Great Britain and Ireland 1997;183(2):131-3.

[6] Hsieh JJ, Purdue MP, Signoretti S, et al. Renal cell carcinoma. Nature Reviews Disease Primers 2017;3:17009.

[7] Motzer RJ, Russo P, Nanus DM, et al. Renal cell carcinoma. Current Problems in Cancer 1997;21(4):185-232.

[8] Decastro GJ, McKiernan JM. Epidemiology, clinical staging and presentation of renal cell carcinoma. Urologic Clinics of North America 2008;35(4):581-92.

[9] Russo P. Renal cell carcinoma: presentation, staging and surgical treatment. Seminars in Oncology 2000;27(2):160-76.

[10] Jones J, Libermann TA. Genomics of renal cell cancer: the biology behind and the therapy ahead. Clinical Cancer Research 2007;13(2 Pt 2):S685-S92.

[11] Cairns P. Renal cell carcinoma. Cancer Biomarkers 2011;9(1-6):461-73.

[12] Hutson TE, Figlin RA. Novel therapeutics for metastatic renal cell carcinoma. Cancer 2009;115(Suppl 10):2361-7.

[13] Uchida T, Izumi H, Kobayashi K, et al. A clinical study of renal cell carcinoma. Hinyokika Kiyo: Acta Urologica Japonica 1985;31(11):1919-25.

[14] Setiawan VW, Stram DO, Nomura AMY, et al. Risk factors for renal cell cancer: the multiethnic cohort. American Journal of Epidemiology 2007;166(8):932-40. https://doi.org/10.1093/aje/kwm170

[15] Chow WH, Gridley G, Fraumeni Jr JF, et al. Obesity, hypertension and the risk of kidney cancer in men. New England Journal of Medicine 2000;343(18):1305-11.

[16] Cho E, Adami HO, Lindblad P. Epidemiology of renal cell cancer. Hematology Oncology Clinics North Am 2011;25(4):651-65.

[17] McLaughlin JK, Lipworth L. Epidemiologic aspects of renal cell cancer. Seminars Oncology 2000;27(2):115-23.

[18] Gibbons RP, Monte JE, Correa RJ Jr, et al. Manifestations of renal cell carcinoma. Urology 1976;8(3):201-6. 